Article

\title{
Sustainable Education through E-Learning: The Case Study of iLearn2.0
}

\author{
Fu-Hsuan Chen (D)
}

check for

updates

Citation: Chen, F.-H. Sustainable Education through E-Learning: The Case Study of iLearn2.0. Sustainability 2021, 13, 10186. https://doi.org/ $10.3390 /$ su131810186

Academic Editor: Clemens Mader

Received: 30 July 2021

Accepted: 8 September 2021

Published: 12 September 2021

Publisher's Note: MDPI stays neutral with regard to jurisdictional claims in published maps and institutional affiliations.

Copyright: (C) 2021 by the author. Licensee MDPI, Basel, Switzerland. This article is an open access article distributed under the terms and conditions of the Creative Commons Attribution (CC BY) license (https:/ / creativecommons.org/licenses/by/ $4.0 /)$.
Department of Political Science, National Taiwan University, Taipei 10617, Taiwan; fhchen@mail.ntcu.edu.tw; Tel.: +886-2-3366-3366; Fax: +886-2-2362-7651

\begin{abstract}
The present paper studies a blended learning approach provided by a university in central Taiwan from 2018 to 2020. In this approach, a Moodle E-learning platform called iLearn2.0 was used along with an onsite classroom. iLearn 2.0 has four major features, including cloud services, mobile learning, flipped classroom, and data analysis. The platform was used during 2018-2020 in the Citizen Participation course, helping the researcher/teacher to design an interactive course content and aiding students to complete classroom activities through their devices. In total, 127 students enrolled in citizen participation courses were taught during 2018-2020, using different teaching methods. In 2018, students studied in a physical classroom. iLearn2.0 was integrated with the physical classroom for the 2019 course; lastly, the iLearn2.0 platform was used alone in 2020. To evaluate the effect of virtual teaching on the students' performance, the researcher used summative assessment as the dependent variable. The findings show that the class that received the iLearn2.0assisted teaching had a significantly better learning performance than the other two classes. However, when researchers used iLearn2.0 alone, both the scores and the feedback from students were lower than those in blended and face-to-face teaching. The results suggest the effectiveness of iLearn2.0 assistance, while learners' performance did not show any significant change in a totally online class. Results were assessed in the view of sustainability, and three sustainability dimensions were found to be improved in the hybrid classroom. The researcher suggests that iLearn 2.0 be integrated with other learning tools for maximum results, as it allows students to have a more diverse learning experience, strengthen sustainable learning, and grasp the progress of their courses and learning activities in a timely manner.
\end{abstract}

Keywords: E-learning; iLearn2.0; sustainability; Microsoft Teams

\section{Introduction}

Sustainable learning has now come to the fore of attention in online classrooms [1]. In today's common digital educational environments, the aim is to improve the teaching and learning effectiveness of teachers and students, to cultivate the scientific and technological capabilities of teachers and students, and provide a place for students to discuss their work and for teachers to accumulate personal teaching materials and create space for sharing class materials [2].

In terms of constructing a platform that facilitates this, Taiwan's University computer center and teaching resources center worked together. This cooperation led to developing iLearn and iLearn2.0 as a virtual educational platform, which was first employed in 2015. Since the outbreak of COVID-19, the application of the platform by university teachers in different courses greatly increased. Ever since, the university has assisted in promoting the use of the platform, getting feedback and opinions from teachers and students on the use of the platform so that it can improve the system.

In Taiwan, this digital learning environment is now widely adopted by colleges and universities to support students' learning in schools. It intends to replace the existing bureaucratic system through its free learning environment and easy-to-manage system. 
Because of its free and digital features, iLearn2.0 contributes to a sustainable education approach where it can successfully achieve educational equality, a UN criterion of sustainable development [3].

The present paper aims to evaluate and compare the effectiveness of this platform with the traditional teaching methods. The design is empirical, and a cognitive approach is adopted. In this approach, the viewpoint of the users (teacher and students) of this education system is studied, and evaluation is made according to their opinions and performance. Since iLearn is a user-based platform, and education is involved, the case studied here consists of three classes taught by one teacher (the present researcher) since 2018 to 2020 in order to address the following questions:

Firstly, can E-learning and online technology improve students' performance?

Secondly, how can the teaching method contribute to the sustainable learning of students in an online platform like iLearn2.0?

Lastly, what difficulties do learners encounter when using iLearn2.0?

\section{Literature Review}

\subsection{E-Learning}

E-learning refers to using computer technology in a learning experience that has led to many changes in traditional learning. In the beginning, people who originally studied psychology talked about the use of artificial intelligence (AI) as a teaching assistant but were unable or afraid to implement it. Before 1970, the behavioral school's programming teaching had to be carried out through a specific machine. Between 1985 and 1995, the emergence of multimedia and hypermedia made the transmission and acquisition of information easier. The teaching environment at this time was affected by cognitive constructivism, which emphasizes the learner's initiative and interaction in the classroom. The uniqueness of E-learning research is that this type of research often introduces a technological tool that is relatively novel to the learning object [4].

The other concept that accompanies E-learning is the Internet. From 1995 to 2005, the Internet was popularized, and a teaching environment designed based on the Internet began to emerge, which had a great deal of influence on the construction of computeraided curricula. The new perspectives of learning emphasized the importance of learning communities, cooperative learning and the authenticity of learning activities or assignments as well as the computer-supported, intentional learning environment, which focused on problem, project, or inquiry-based learning activities [5]. After 2005, learning entered the era of mobile phones and wireless networks. iPads replaced computers in classrooms by and large; a specific example is a researcher who used smartphones to integrate problemsolving plots and led students to visit museums [6].

There are many forms of using virtual space as a platform to promote digital learning. Some online platforms used as online professional learning communities include Moodle, Wiki, Blog, Skype, and FB. A number of empirical studies on these platforms have been conducted with a similar research goal, i.e., the use of technology to break through the constraints of geography and time and support the collaborative learning of participating teachers and students in groups [1,7-12].

The changes in E-learning theory can be divided into three stages: the behaviorist/empiricist view as the first stage was represented by the behaviorist school of thought. The second phase, known as the cognitive/empiricist view, was represented by the cognitive school, focused on information processing and cognitive constructivism. The third phase, the situational/pragmatic-pragmatic/socio-historical view, was represented by situational cognitive theory and social constructivism [13].

Common variables in E-learning research include media and teaching materials, teaching methods and learning methods, and learner characteristics [1,7-10,13-22]. The traditional E-learning model uses book digitization and online platforms to transform traditional classroom learning into an online learning model that can be used to learn online anytime, anywhere. However, this model still uses lecturing, passive participation of users, 
and top-down content for teaching and learning [1,2,7-12,21,23-26]. E-learning 2.0, a coined term for collaborative learning through technologies, involves student-centered learning, active learning and participation, collaborative cooperation and discussion, bottom-up learning mode, learning content generated by users, and learning community generated by common learning interests and goals groups [22].

\subsection{Educational Technology and E-Learning}

An important aspect to E-learning is sustainable educational technology. Since 2020, COVID-19 has affected the lives of many people all over the world. For the health and safety of students, the educators and faculty staff of many schools around the world have taken strict measures for epidemic prevention or even temporary close-downs. In this regard, schools are looking for ways to enable students to continue to participate in learning sustainably. Sustainability in learning can best be defined by the United Nations initiative that aims to bring relevant and curated learning solutions on sustainable development topics to individuals and organizations $[8,10,23,27]$. Through the cooperation of the United Nations, multilateral organizations, and sustainable development partners from universities, civil society, academia, and the private sector, UN SDG provides a unique gateway that empowers individuals and organizations through an informed decision when selecting among a wealth of SDG-related learning products and services that are currently available. Sustainable education is formal and informal education and professional development that continually renews itself, incorporating principles and aspirations of sustainability in design and delivery, and educating in ways that promote sustainable learning." It is less structured and "fixed" than conventional education and operates more organically and responsive [28].

\section{Sustainable Learning in Education and Education Transformation}

Sustainable learning in education (hereafter SLE) is a learning and teaching philosophy based on sustainability principles, especially in the concept of "learning to learn," which is similar to lifelong learning [20]. Sustainability as a key element in today's pedagogical paradigms has many implications for teaching methodologies and materials. Online courses in the post-epidemic era should have four key components of SLE: renewal and relearning, independent and collaborative learning, active learning, and transferability [29]. However, there are various reasons why current pedagogical models cannot keep up with the non-lasting nature of technological and social changes, emphasizing the need for new learning and teaching paradigms. As a result, education is being transformed to different learning contexts with the aid of technology. The new technologies are changing our thoughts, concepts, and educational goals, not just our methodology [30].

In face-to-face learning, students are completely assessed by teachers. Teachers are their main source of information. As a result, the quality of learning depends to a large extent on them. There is a prevailing tendency for teachers to assume control over learning processes and view students as passive receivers of knowledge [31]. For sustainability, however, student engagement and leadership is of paramount importance. The curriculum and teaching practice of higher education institutions must improve students' critical and reflective thinking skills through interdisciplinary ways and even making substantial changes to the curriculum, including providing more effective and socially fair higher education for sustainable development [32].

For sustainable development, E-learning has been used in education especially in the context of lifelong learning and adult education, and some studies have been conducted to evaluate the results of E-learning for sustainable development in higher education. Scholars analyze students' motivation, satisfaction, results, abilities, and attitudes and believe that E-learning in higher education is very effective for lifelong learning in education for sustainable development [33].

In E-learning, teachers mostly use an online platform and many technological advancements that have improved the role of students and enhanced student activities, resulting in 
relevant learning [34-36]. The oriented and transformative learning approaches should be situated in higher education institutions because they generate relevant learning for students [37-43]. Students' assessment can also be carried out more conveniently using technology tools. The quality of learning depends to a large extent on the teacher's digital training level and teaching style [14].

\section{3. iLearn 2.0}

iLearn is an online assistant first launched in 2000. It was used in university courses to integrate technology with education in line with the SLE approach [23]. In 2015, the iLearn system was upgraded and migrated to the iLearn 2.0 version. The upgraded platform continues to use "Internet Classroom". The platform has been also used by businesses for distance learning and for conferencing, the same as Kahoot [44]. The system of iLearn 2.0 module is Moodle. The main change of iLearn2.0 is that teachers can design the teaching plan more flexibly, and the new platform presents a single page. The method is closer to social network models, increasing the affinity of students [45]. In this platform, to meet the users' demands, the teaching resource center re-examines and plans the functional blocks, resource classification and layout of the online classroom, re-courses, university class tools, and other modules so that users can find the resources they need to use more easily. In the iLearn2.0 operation interface, the basic functions include (see Figure 1).

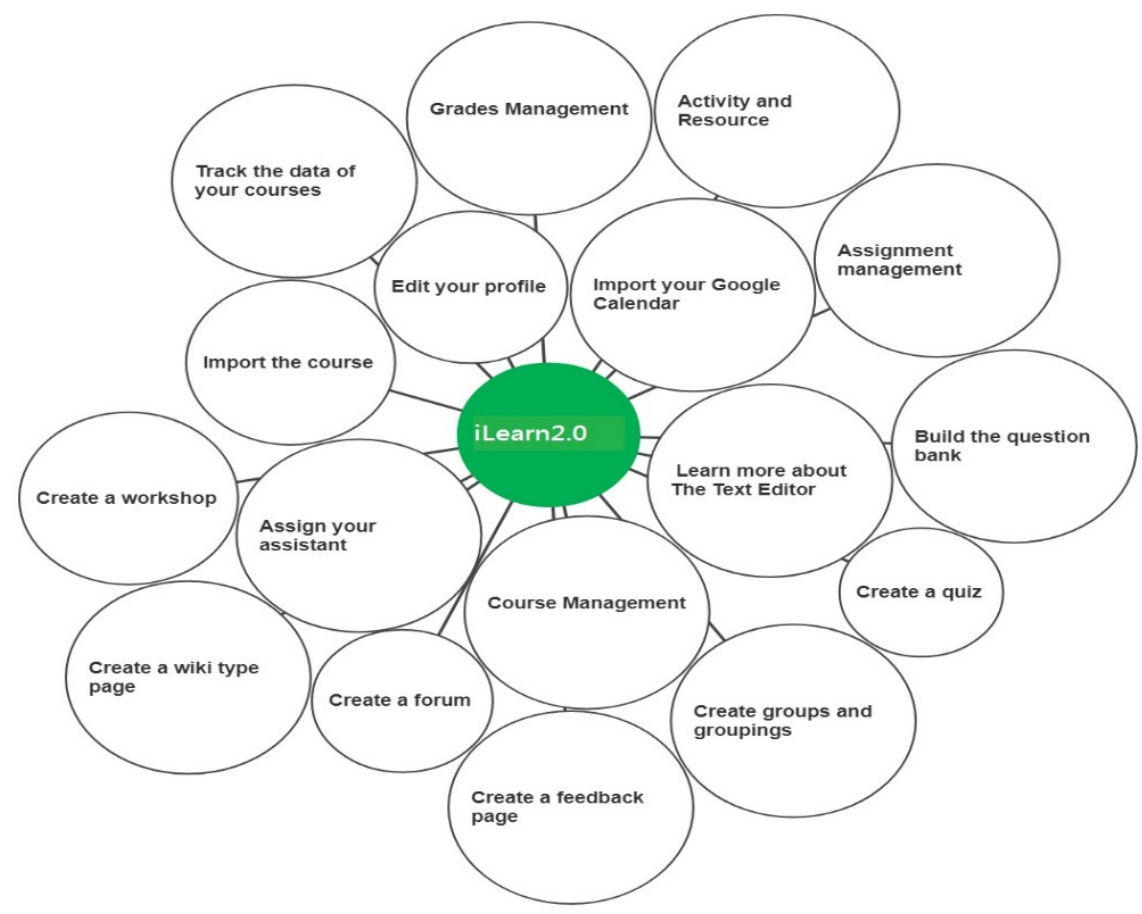

Figure 1. The Functions of iLearn2.0.

Due to the difference in the core architecture of the iLearn system, the user's operation method changed slightly compared to the previous version. The online classroom (iLearn2.0) system also introduces "Learning Guidance" and "Learning Portfolio". It helps teachers and students in class to use the iLearn 2.0 easily. The iLearn 2.0 live video streaming software is easy to operate, allowing teachers to grasp the learning status of each student in real time. In addition, the live video software supports functions, such as "recording", "screen sharing", "whiteboard" and "chat interaction". The content of the lectures can be imported into iLearn2.0 regularly. During the video process, students are also able to ask teachers about the points they do not understand, to ensure that the right of every student (i.e., to be taught) is saved. 


\section{Materials and Methods}

In this study, summative assessment and survey are used for data collection. The researcher studied the performance of three classes of Citizen Participation Practice in F University from 2018 to 2020 as the research participants and adopted three teaching methods to teach "the citizen participation" course in three consecutive years. The duration of the course is 12 weeks. In 2018, 47 students enrolled in the course and received faceto-face instruction and other traditional teaching methods. In the teaching process of this class, the teacher did not use iLearn 2.0 and did not ask questions. For the 27 students who took the course in 2019, the teacher used iLearn2.0 assistance to run the class. In this hybrid approach, the lectures were given face to face, and the online activities included students reports, homework submission, group discussions, and the feedback board. Finally, for the 53 students who took the course in 2020, the teachers used only iLearn to teach. Due to the lock-down situation brought by the pandemic, the class was run fully online. Lectures were given through Microsoft Teams app, which was incorporated into iLearn 2.0, and other activities were also conducted using the platform.

All the subjects were first-year college students of architecture (2018-2020). The teacher, course requirements, course content, reading range, and mid-term and final grading standards for each group were exactly the same (see Table 1).

Table 1. Research Subjects.

\begin{tabular}{cllc}
\hline Year & Status & N & Teaching Style \\
\hline 2018 & First-year college students of architecture & 47 & Face-to-face (onsite) \\
\hline 2019 & First-year college students of architecture & 27 & Hybrid: onsite and iLearn2.0-assisted \\
\hline 2020 & First-year college students of architecture & 53 & Fully online through iLearn 2.0 system \\
\hline
\end{tabular}

The author uses iLearn along with Microsoft Teams, a virtual hub that can connect teachers with up to 250 students at a time. Students can join their class via any device to interact and collaborate with their teachers and classmates in real time. Courses can be recorded on iLearn, and the video and other learning files can be collected on Microsoft Teams. Students can review and personalize their learning materials.

\section{Results and Findings}

Researchers tried their best to control the factors that may interfere with the experiment results. However, the novelty of educational technology and other confounding variables are still the research limitations that may affect the results of any experiment. It should be also noted that in the research of digital learning and the complexity and uncontrollability of the research situation often exceed expectations.

The researcher used the students' summative assessment as the dependent variable. In 2018, the Citizen Participation course is divided into three themes of sustainable energy, digital currency, and the game industry for discussion with groups of 3-5 students. The United Nations SDG indicators were included for the first time in the citizen participation curriculum. The SDGs were briefly introduced for discussion in the class. The analysis of the final grades in Figure 2 shows that the highest score at the end of the semester was 91 points, the average score was 76.09 points, and the standard deviation was 13.46 (see Figure 2). 


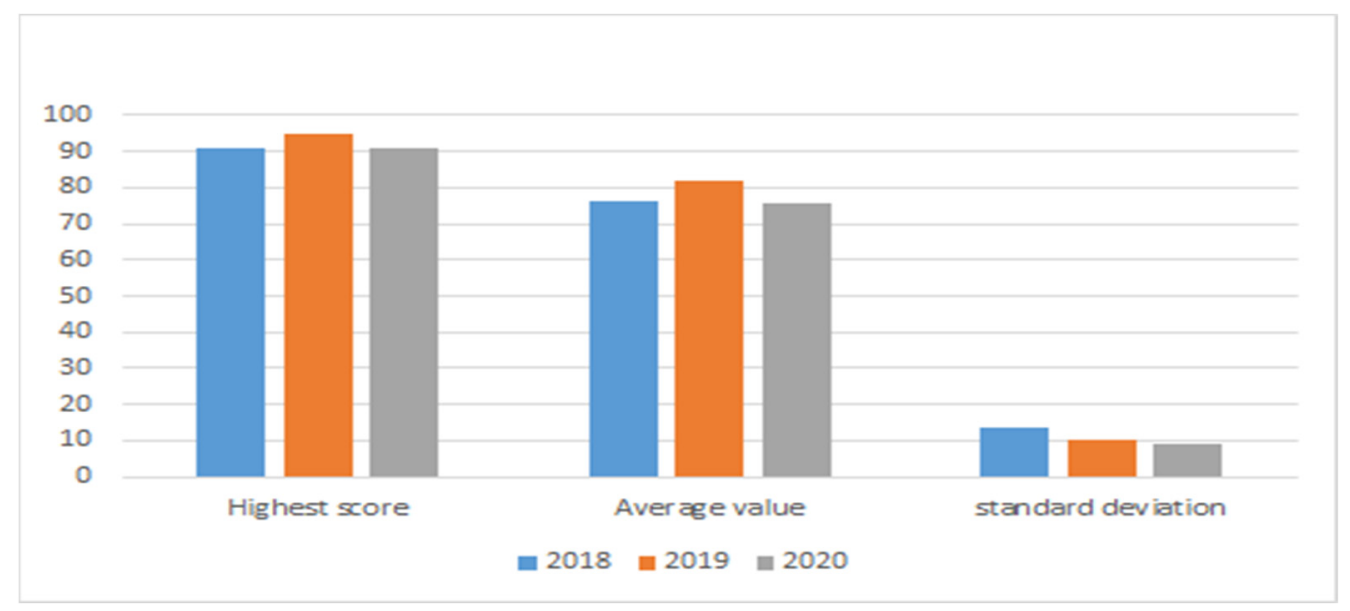

Figure 2. The Summative assessment of students in citizen participation course in 2018-2020.

In 2019, iLearn2.0 was used for group discussion and questioning to teach students. The researcher edited the teaching profile and used course management to modify the course according to online requirements. A few weeks before the class, the teacher introduced and analyzed the SDGs concept. The teacher had to obtain a list of students first in order to complete the grouping of students according to the core compulsory regulations and avoid group activities that would allow free-riding to some students. During the course, each group of students was required to introduce and analyze one of these topics through a discussion panel with members: sustainable energy, digital currency, and the game industry, according to the SDGs framework. This could train their case analysis and reporting skills and also demonstrate the result of teamwork/discussion. At that time, all students had to participate in the evaluation and feedback of the group to create an interesting, exciting, and energetic online learning atmosphere.

After listening to different case presentations and analysis every week, students had to fill out a Google form to submit their learning experience. The instructor summarized these experiences and provided supplementary or extended explanations for them every other week. The students listened to the overall feedback from the teacher and also learned the diverse opinions and different ideas of other students, which cultivated students' ability to observe, identify, and participate in public issues. The instructor specified the subject and allowed students to observe and analyze the reports. Students could discuss the content of the report with the teacher online to complete their report. Since the number of students in this class was less than 30 , the online interaction and discussion could be managed well.

In 2019, the author designed, implemented, and operated project-based learning in multimedia so that students could use technology flexibly, learn more actively, or move to a higher level of learning. After several practical experiences, the aforementioned ideals seemed difficult to be fulfilled. The author started to increase the interactive part of the learning environment, that is, increase the use of online discussion areas. Due to the lack of experience in using iLearn2.0 in the classroom, only a part of the discussion in the traditional classroom was transferred to the new media.

In this year, the maximum score of the students was 95 , the average score was 81.85 , and the standard deviation was 9.92. In addition, teachers received higher satisfaction feedback from students compared to other years (see Figure 2).

In 2020, when COVID-19 broke out, iLearn was used to conduct courses for 53 freshman architecture students. The author used iLearn 2.0 and Microsoft Teams for grouping the students and the Microsoft team for lecturing and receiving students' reports. Although the teachers and classmates put in a lot of energy, after a period of time, they still felt that the results were not good [14]. The overall experience proved that the iLearn 2.0 can provide a virtual learning environment that allows teachers to create, store, access, and use learning resources, for course planning, learner participation, and management. In 
other platform services, teachers and students are provided with a more complete learning process information to strengthen the students' learning guidance function.

In 2020, The students' highest score was 91 points, the average score was 75.68 points, and the standard deviation was 8.84. The performance of students was worse than those at onsite and hybrid courses (see Figure 2).

In the following, a number of disadvantages observed in this experience are given.

When using iLearn2.0 along with Microsoft TEAMS for online teaching, students are prone to not having prepared the related equipment (camera, microphone, etc.), and some students may not be skilled in using Microsoft TEAMS. Some students have internet delays, affecting the class quality as well. Moreover, the manual grouping of Microsoft TEAMS can only be done after students get online, which is time-consuming. After starting the group meeting, students have no way to maintain the big meeting room synchronously. Group voting will be repetitive, making the scores relatively inaccurate. Although these shortcomings can exist in the online activities of a hybrid classroom, students were more controlled and preserved in their studies due to constant contact with their teacher.

Despite the above shortcomings, using Microsoft TEAMS for teaching still has the following advantages:

1. It can instantly reflect whether students are online, and the system can record the login and logout time of each student, which helps to identify being late, leaving early, and absenteeism.

2. It can record attendance in a system, which is convenient for saving credentials.

3. In a physical class, the teaching will be affected by the students' seat, and it is more difficult to talk to students in the middle and back rows. Online teaching can get rid of the limitation of seat distance.

4. In a physical class, the students report on stage and face stage fright due to facing the whole class.

5. The researcher can directly provide online information and web pages to boost students' knowledge.

6. Compared with physical courses, students are more courageous in speaking and asking questions, and those who are shy in terms of speaking are willing to express their opinions in words.

7. Students can use the Internet to find necessary information in real time to increase their self-study ability.

8. The great advantage of online teaching is that it is less likely to be disturbed by students in the classroom.

9. Students have good information literacy and express report content neatly.

Students scored their feedback on their class via a questionnaire uploaded on university website. The scoring was done using a Likert five-point scale in which 5 points refers to "strongly agree," and 0 point means "strongly disagree". The experiment results show that the students who received onsite teaching plus iLearn2.0 assisted activities had a significantly better learning experience than the other two groups. However, when researchers simply used iLearn2.0, the feedback from students was lower than that of the traditional teaching methods (see Figure 3). 


\section{Citizen Participation}

\section{5}

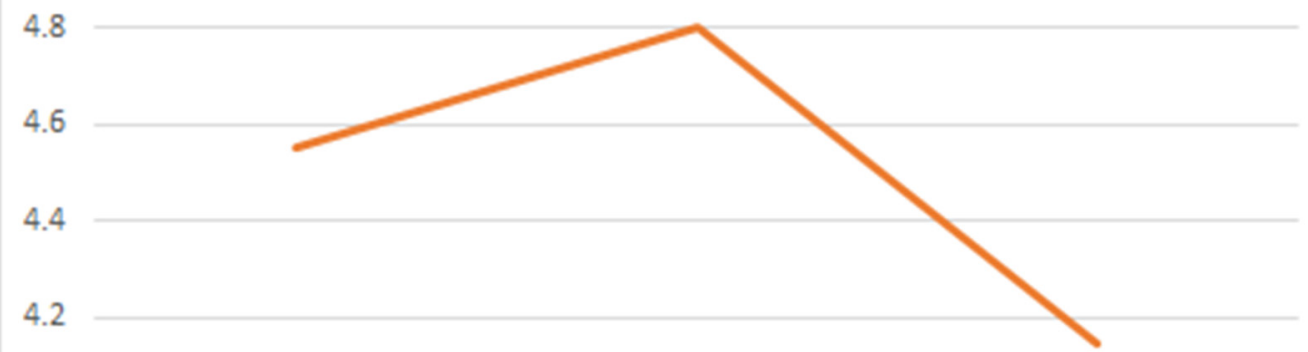

4

3.8

2018 students' feedback 2019 students' feedback 2020 students' feedback

Figure 3. Student ratings of the citizen participation course 2018-2020.

\section{Discussion}

The researcher conducted the research based on these three aspects: student performance assessment, teacher/course evaluation (feedback given by the student), and the problems encountered in reports. The students' total score is calculated from the coursework $(30 \%)$, oral report $(30 \%)$, final report $(30 \%)$, and the course participation score $(10 \%)$. The results were used to reflect the students' performance throughout the course, which highlighted the importance of using technology for improving learning quality. In the second analysis factor, students' feedback referred to many technology problems encountered during the course. In order to improve the stability of online classroom system services and the convenience of platform use, mobile devices should be supported largely, and course interaction methods should increase. Novelty effect is an important factor that can influence the learning experience when many digital technologies are introduced.

To respond to the opportunities and challenges brought about by technological advances, the United Nations Sustainable Development goals for education in 2030 emphasize the role of education in sustainable development in the context. SDG education goal addresses the need to change in education and upgrade the level of education to higher degrees. This framework enables educators and learners to have a greater vision and understanding of the role of education in sustainable development [46]. Sustainable development in education can be discussed from three dimensions: cognitive learning, social and emotional learning, and behavioral learning $[3,23,31]$. In the following, these dimensions are discussed according to the findings and results of this study.

\subsection{Cognitive Learning Dimension}

According to SDG, it is necessary to understand sustainability challenges and their complex interlinkages and to explore disruptive ideas and alternative solutions. Based on the performance of students in the citizen participation course, students had the best results in the 2019 hybrid approach, and they also showed the highest level of understanding of SDGs. However, in the fully online course, most students showed impatience, and the results were not as good as face-to-face or hybrid teaching methods (see Figure 4). 


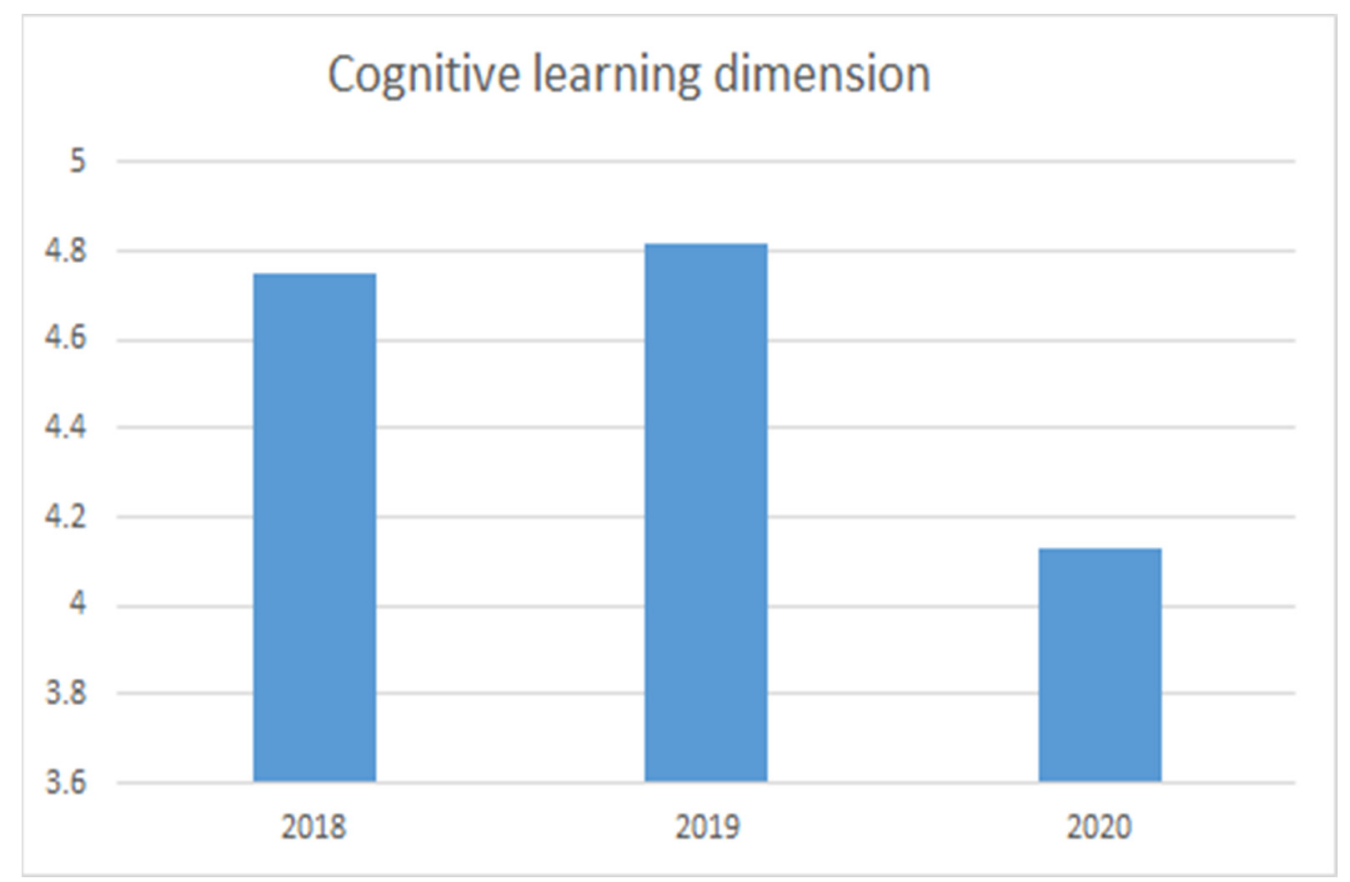

Figure 4. Students' rating of cognitive learning dimension. Students' score of the course was given out of 5 .

In 2018, the researcher used traditional lecturing in class, and students were not familiar with the use of iLearn2.0. ILearn 2.0 was only used for the usual homework submission, attendance, and grade management. In 2019, hybrid teaching was used. iLearn 2.0 was employed for community discussions. Students could form groups and discuss through iLearn 2.0 and submit their homework (see Figure 4).

"University resources have always been abundant, but the use of iLearn2.0 at the beginning really made me uncomfortable. Today I learned about the iLearn collaboration platform. I think it is a relatively primitive space. But this also allows us to understand how a blog is set up." (Student A-2019)

In 2020, there were 19 MOOCs online courses produced on this platform. The researcher used iLearn2.0 and Microsoft Teams to run an online class. From a cognitive learning dimension, students learn about the merits and demerits of online teaching using iLearn2.0. For example, two students stated:

"Today at noon, I went to the computer classroom with my team members to learn how to use the collaboration platform. I discovered that university resources are quite information-based. There are not only online resources such as iLearn2.0, G-Mail etc., Today I learned how to use the collaboration platform, Feel very fulfilling." (Student B-2020)

"Why do I always feel that the school's revised version of iLearn2.0 has become unusable? Why can't it open? Total maintenance? Is there a problem with my phone?The iLearn 2.0 really don't see a bunch of my courses. The student information system has it. Ah, those courses still have to teach homework." (Student D-2020)

\subsection{Social and Emotional Learning Dimension}

It is pointed out in SDGs guidelines that in education, one needs to build core values and attitudes for sustainability, cultivate empathy and compassion for other people and the planet, and motivate to lead the change [3]. According to the feedback of students, the experience of learning through an online platform helped the students to learn more skills 
beyond their course content. They developed empathy and compassion when they faced COVID-19, while their teachers strived for continuing education by any means.

If a student is shy and embarrassed to go on class stage to report, online course reporting can be used instead of speaking in public. In general, students seem to be interested in the structure and content of civic participation courses in 2019 and 2020. The results also show that most classroom activities are welcomed by students. A student asserted that iLearn2.0 provides him with more and better abilities compared to face-to-face courses:

"It's very exciting to interact with classmates through different learning platforms. I hope that in every experiment and attempt. We can all learn a little more." (Student C-2020)

"In addition, the civic participation course has enabled me to achieve very positive development in sustainability education skills. In addition to group courses, SDGs and other reflection, implementation and evaluation of sustainability provides important tools, and these actions can change attitudes and behaviors." (Student D-2019)

The other stated merits of this online platform include saving time, no need to dress up, taking longer breaks, and increasing opportunities for time use. At the same time, online classes can be free from negative interference from other students. Course recording is good for repetitive learning or after-school learning. Electronic media can make teaching content more clearly presented. Online learning can also make students who are introverted and afraid to speak willing to ask questions, and part of the learning pressure is reduced (for example, canceling exams and changing to reports, eliminating the need to meet students who do not want to meet). Finally, the convenience of the home environment provides favorable support for online learning. In the social and emotional learning dimension, the gap between face-to-face class and hybrid teaching has widened, and the students satisfaction with the hybrid teaching is the highest (see Figure 5).

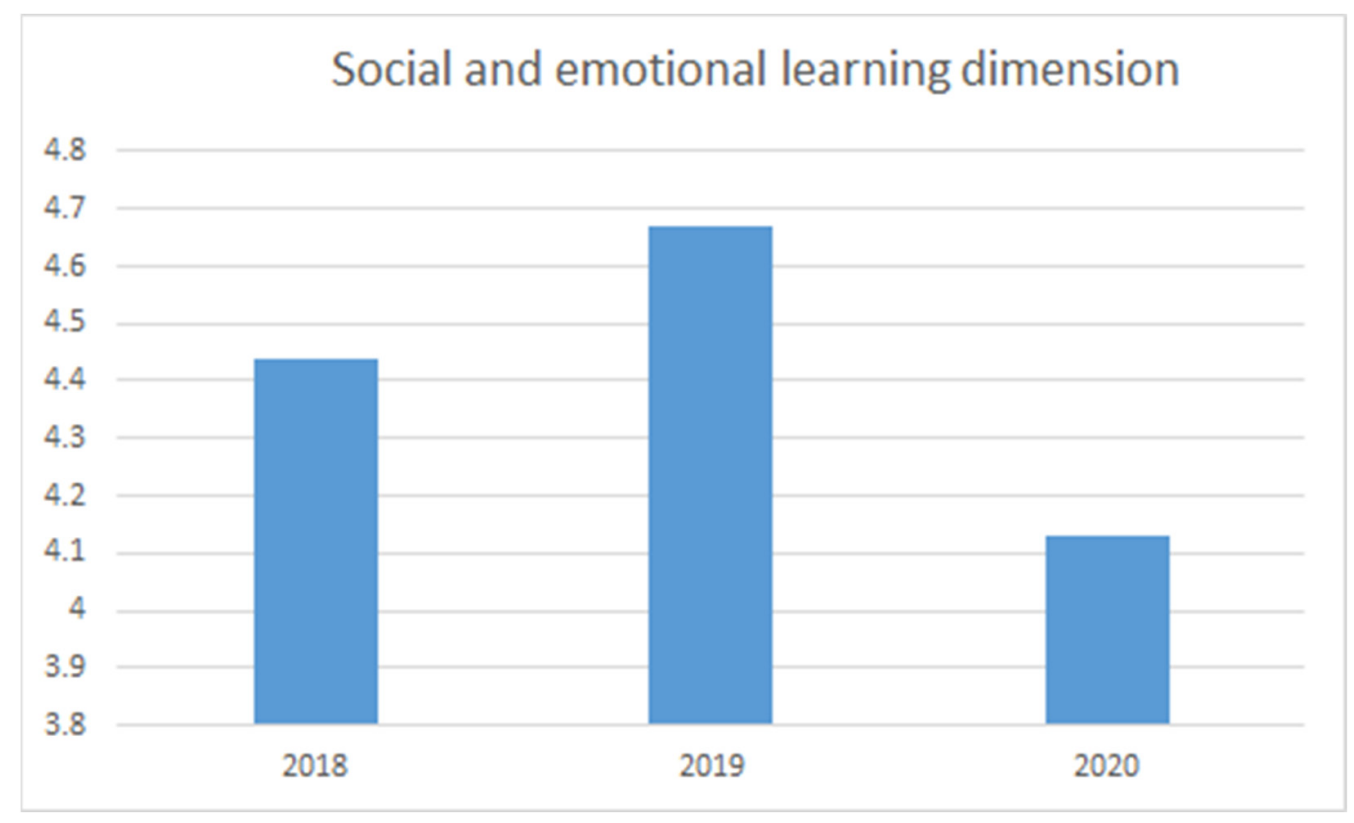

Figure 5. Students' rating of social and emotional learning dimension.

\subsection{Behavioural Learning Dimension}

According to SDGs, education practitioners need to take practical actions for the sustainable transformation of individuals, society, and politics through education. In the citizen participation courses offered by the author, online platforms were used to achieve sustainable transformation in the personal, social, and political fields. In the curriculum, 
the new method of mixed E-learning, which was designed to develop students' ability, proved to have the best effect and the best response from students.

E-learning can raise inequality in the learning environment since the used technology by students will heavily depend on their living condition. Therefore, the Internet and devices may not be equally accessible for all potential beneficiaries of E-learning. The main shortcomings of online courses are as follows: teacher-student interaction is not easy, the interaction between students is limited, and the lack of control restraints. At the same time, the concentration of students will be reduced.

"I logged into iLearn2.0 with a laptop. It keeps appearing. The network I want to visit contains malicious software. Attackers will try to install malicious programs on the computer through iLearn2.0? Is anyone like me? What should I do now?" (Student E-2020)

“What's wrong with iLearn2.0. Recently, e-mails often receive messages from teachers who announce their grades, but sometimes they also receive responses from teachers? Obviously studying French, the students responded that the content of the French teacher was love psychology. Clicking on the personal information showed that he did not take this subject. Is it broken again?" (Student F-2020)

If all the courses are changed to online courses, it will exacerbate student's high burden on eyesight.

"At the end of the semester's online exam, I originally thought that I could easily pass the exam at home. It didn't happen at all...If you have any questions about the topic, you can't ask questions. Looking at a bunch of numbers on the computer, the eyes can't bear it. The key point will also automatically pop out of the virus scan, and then the test paper will be sent out...I don't know if I can be a little bit more accommodating in the calculation of online test scores. It's really hard for me to crash immediately after the first use." (Student G-2020)

The homework after class increased significantly, which is considered as a drawback by many students. Sometimes, when the teacher has no access to students in the class who need to be controlled more, he gives them more homework.

“The remote online teaching teachers speak very quickly, and it is useless to respond to the teaching assistant. AfterE-learning, how about a bunch of homework? There are still bugs in the online exam, hey AI University." (Student $\mathrm{H}-2020)$

The summative assessment implies that iLearn2.0 is a charging environment that is not restricted by time and place and can be used for online non-synchronized after-school discussions anytime and anywhere, allowing students to recharge all year round. However, there are some weaknesses that should be considered by the school authorities, such as removing the software bugs, improving the accessibility of the needed equipment for the needy students, and improving the user-experience and introductory courses [24].

In the behavioral learning dimension, students' opinions reinforced the quantitative data, and the gap between the online class and the hybrid class widened. Students' satisfaction with the hybrid class was higher compared to other years (see Figure 6). However, this dimension witnessed some drawbacks in this online platform. The analysis of iLearn 2.0 online class shows the platform has some major problems:

1. The effectiveness of online teaching/lecturing is poor because it is not face-to-face, and it is difficult to control the learning and discussion of the whole class.

2. Some students are only connected to attend the meeting but are not listening or even not in the position at all. The number of missed study slips has greatly increased. If students were asked to turn on the video, some students refused on the grounds that the computer does not have a video camera, and it was difficult to understand their learning situation. 
3. During the roll call, some students do not go online or do not respond and would be registered as absent. In some cases, the teacher was asked several days later to remove their absenteeism on the grounds of network problems, system problems, etc.

4. The students' microphone is not always prepared, making it difficult to answer the teacher's questions immediately.

5. Less than 10 students in each class are willing to interact.

6. Sometimes the students who are appointed for a task will leave temporarily, and no one can answer the question.

7. There is a lack of physical class time and the variety and flexibility of design activities. Students who are unfamiliar with each other have less chance to directly contact each other and produce ideas for discussion.

8. Students bring different excuses for not opening their camera and hiding behind the screen, resulting in poor overall interaction effect, lacking a sense of face-to-face interaction.

9. Since the teacher needs to wait for learning feedback, the teaching effect is poor, and grouping and discussion are not easy to carry out.

10. The effectiveness of group discussion needs to be evaluated, and there is no way to really understand the division of labor within the group (teacher cannot watch multiple groups at the same time). Generally speaking, students' autonomy becomes more important for the effectiveness of learning.

11. The students who do not pay attention to the teacher or class are less controllable.

12. The teacher cannot monitor the interaction of students.

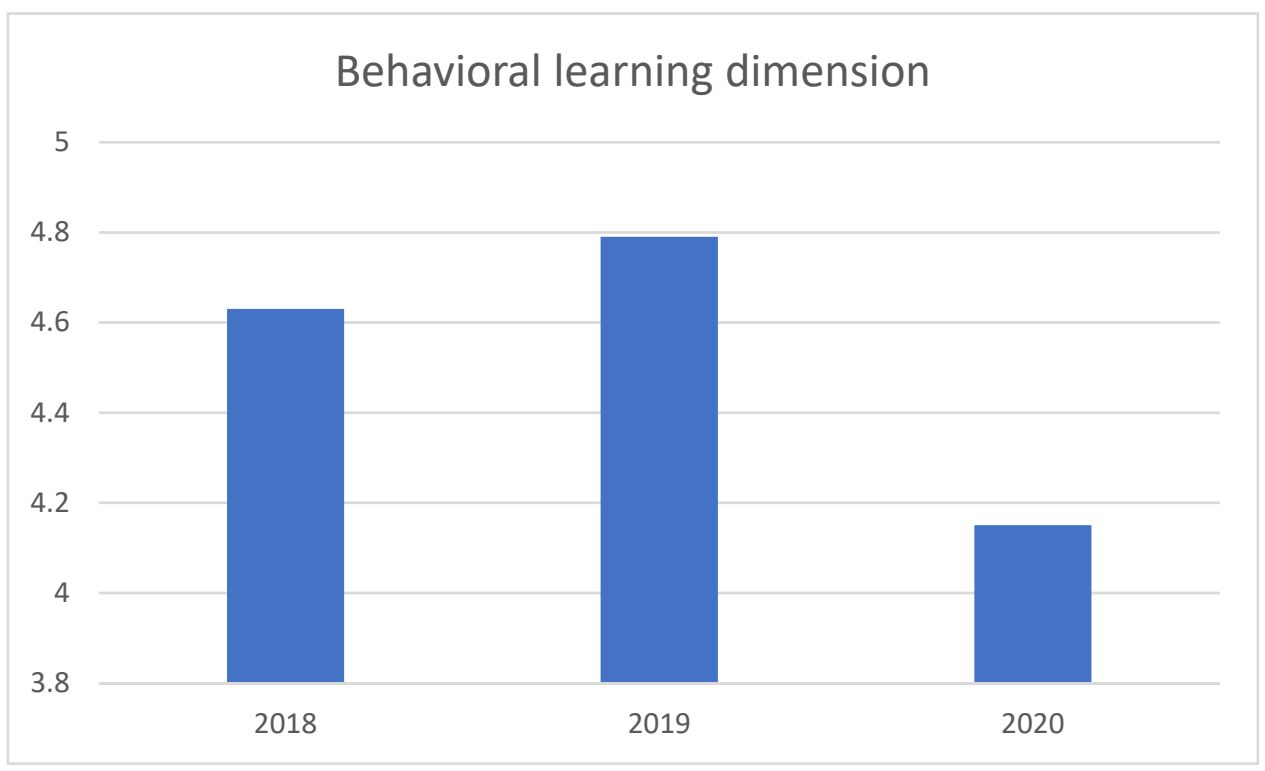

Figure 6. Students' rating of behavioral learning dimension.

Apart from the benefits and drawbacks of iLearn2.0 for students and the classroom, the author saw advantages in using this platform for improving the quality of teaching experience for both sides. iLearn2.0 acts as a powerful tool for data collection that tracks learner activities, successes, and difficulties. iLearn2.0 helped the author/teacher with the following:

1. Attendance: Use ADMIN TOOL Attendance: students can sign in to the course, and the teacher only needs to check those who did not.

2. Midterm Warning: notifies the students about their performance.

3. Assignment: Go to "iLearn $2 \rightarrow$ add an activity or resource $\rightarrow$ assignments" to make and collect assignments. 
4. Discussion: Go to "iLearn $2 \rightarrow$ add an activity or resource $\rightarrow$ discussion area": students can discuss topics, which can be in pairs, groups, or one-on-one.

5. Quiz: Go to "iLearn $\rightarrow$ add an activity or resource $\rightarrow$ quiz: students can take online quizzes, time-limited exams, or after-school exercises.

6. Announcement: Use the announcement page to make class-related announcements and send group emails.

7. Contact students:

(1) Contact individuals or groups by email.

(2) Contact students using messages.

(3) Use the Team Chat room to communicate with students.

8. Review: Students can download the video of the day at Teams chat or O365 Stream. Teachers can upload videos and materials.

9. Grades management: Use ADMIN TOOL gradebook.

\section{Conclusions}

The unprecedented situation of the COVID-19 pandemic caused a fundamental transformation in the education system. From a teaching perspective, E-learning is an effective, sustainable learning solution under current and future conditions [10]. One of the main sustainability goals of the United Nations 2030 Agenda for Sustainable Development (Goal 4) focuses on the equal right of all people to receive fair and quality education. In this regard, teachers play a vital role because sustainable education involves "teacher participation and authorization, motivation, and support in a system with sufficient resources and efficient and effective management" [3]. Content is disseminated through the education process so that we can talk about the sustainability of the education. In the Internet industry and education scene in the post-pandemic era, the keyword born is E-learning [27]. Many teachers believe that online teaching provides them with ideas to change traditional classroom teaching. As a learning mode that is not limited by time or space, E-learning allows teachers to have a flexible and convenient learning environment to expand their professional knowledge [4].

This research has investigated the integration of an online virtual learning Moodle called iLearn2.0 and offline physical classroom. iLearn 2.0 has four major features, including cloud services, mobile learning, flipped classrooms. and data analysis. Through the 2018-2020 citizen participation courses, the author of this paper (as the teacher) designed interactive course content based on iLearn 2.0, where students could complete classroom interactive activities through their mobile phones or other devices.

With regard to the three dimensions discussed in this paper, although iLearn2.0 can be used to conduct online cooperation through online discussion rooms, the learning of students is not as effective as the hybrid E-learning and physical teaching. However, there are some factors that might be contributing and affecting this finding: as the participating students are all freshmen, they might not have complete computer knowledge and would not use the synchronized discussion on the Internet too frequently. This is, however, just a precautionary statement. Our findings provide that in iLearn 2.0, the barriers to login and the difficulty of operation are minimized after long-term monitoring of the platform. Many teachers think that iLearn2.0 provided them with ideas for reforming and revitalizing traditional classroom teaching. The key role of higher education in creating a sustainable future requires a new human perspective to conceive a sustainable future. With the advancement of devices such as mobile phones and tablets, in the field of sustainable education, more and more attention will be paid to mobile learning systems that integrate mobile technology into the teaching environment [23]. Hybrid learning is a new approach in teaching focusing on meaningful learning. With the assistance of iLearn2.0, students ${ }^{\prime}$ learning is more meaningful in terms of sustainability's three dimensions because this approach takes students to the center of focus in the course, allowing them to participate equally in all dimensions. 
According to the sustainable development education initiative and background, our findings may add to the existing education plans and future development: it is worth noting that students not only attach great importance to coping with challenges but also to carrying on a dialogue with stakeholders through feedback. In a physical and online hybrid learning environment, students come to the center of attention through multiple channels of participation [35,47]. Technological diversity and transformation-oriented learning are emerging to cope with the changes of the time. Higher education should provide students with the possibility of a participatory and vivid change practice $[40,48]$.

Funding: This research received no external funding.

Institutional Review Board Statement: Not applicable.

Informed Consent Statement: Not applicable.

Data Availability Statement: The data presented in this study are available on request from the corresponding author. The data are not publicly available due to privacy.

Conflicts of Interest: The author declares no conflict of interest.

\section{References}

1. Edelhauser, E.; Lupu-Dima, L. Is Romania Prepared for ELearning during the COVID-19 Pandemic? Sustainability 2020, $12,5438$. [CrossRef]

2. Mailizar, M.; Almanthari, A.; Maulina, S.; Bruce, S. Secondary School Mathematics Teachers' Views on E-Learning Implementation Barriers during the COVID-19 Pandemic: The Case of Indonesia. Eurasia J. Math. Sci. Technol. Educ. 2020, 16, em1860. [CrossRef]

3. UNESCO. Education for Sustainable Development: A Roadmap; UNESCO: Paris, France, 2020.

4. Chen, H.-R.; Tseng, H.-F. Factors That Influence Acceptance of Web-Based e-Learning Systems for the in-Service Education of Junior High School Teachers in Taiwan. Eval. Program Plan. 2012, 35, 398-406. [CrossRef] [PubMed]

5. Scardamalia, M. Instruction, Learning, and Knowledge Building: Harnessing Theory, Design, and Innovation Dynamics. Educ. Technol. 2004, 44, 30-33.

6. Sung, Y.-T.; Chang, K.-E.; Hou, H.-T.; Chen, P.-F. Designing an Electronic Guidebook for Learning Engagement in a Museum of History. Comput. Hum. Behav. 2010, 26, 74-83. [CrossRef]

7. Cacheiro-Gonzalez, M.L.; Medina-Rivilla, A.; Dominguez-Garrido, M.C.; Medina-Dominguez, M. The Learning Platform in Distance Higher Education: Student's Perceptions. Turk. Online J. Distance Educ. 2019, 20, 71-95. [CrossRef]

8. Coman, C.; TTîru, L.G.; Meseșan-Schmitz, L.; Stanciu, C.; Bularca, M.C. Online Teaching and Learning in Higher Education during the Coronavirus Pandemic: Students' Perspective. Sustainability 2020, 12, 10367. [CrossRef]

9. Galy, E.; Downey, C.; Johnson, J. The Effect of Using E-Learning Tools in Online and Campus-Based Classrooms on Student Performance. J. Inf. Technol. Educ. Res. 2011, 10, 209-230. [CrossRef]

10. Ionescu, C.A.; Paschia, L.; Gudanescu Nicolau, N.L.; Stanescu, S.G.; Neacsu Stancescu, V.M.; Coman, M.D.; Uzlau, M.C. Sustainability Analysis of the E-Learning Education System during Pandemic Period-COVID-19 in Romania. Sustainability 2020, 12, 9030. [CrossRef]

11. Mohmmed, A.O.; Khidhir, B.A.; Nazeer, A.; Vijayan, V.J. Emergency Remote Teaching during Coronavirus Pandemic: The Current Trend and Future Directive at Middle East College Oman. Innov. Infrastruct. Solut. 2020, 5, 72. [CrossRef]

12. Obrad, C. Constraints and Consequences of Online Teaching. Sustainability 2020, 12, 6982. [CrossRef]

13. Greeno, J.G.; Collins, A.M.; Resnick, L.B. Cognition and learning. In Handbook of Educational Psychology; Prentice Hall International: London, UK, 1996; pp. 15-46. ISBN 978-0-02-897089-9.

14. Adnan, M. Online Learning amid the COVID-19 Pandemic: Students Perspectives. J. Pedagog. Sociol. Psychol. 2020, 1, 45-51. [CrossRef]

15. Almarabeh, T. Students' Perceptions of E-Learning at the University of Jordan. Int. J. Emerg. Technol. Learn. IJET 2014, 9, 31. [CrossRef]

16. Alqabbani, S.; Almuwais, A.; Benajiba, N.; Almoayad, F. Readiness towards Emergency Shifting to Remote Learning during COVID-19 Pandemic among University Instructors. E-Learn. Digit. Media 2021, 18, 460-479. [CrossRef]

17. Alsaaty, F.M.; Carter, E.; Abrahams, D.; Alshameri, F. Traditional Versus Online Learning in Institutions of Higher Education: Minority Business Students' Perceptions. Bus. Manag. Res. 2016, 5, 31-41. [CrossRef]

18. Beaunoyer, E.; Dupéré, S.; Guitton, M.J. COVID-19 and Digital Inequalities: Reciprocal Impacts and Mitigation Strategies. Comput. Hum. Behav. 2020, 111, 106424. [CrossRef] [PubMed]

19. Butz, N.T.; Stupnisky, R.H.; Pekrun, R. Students' Emotions for Achievement and Technology Use in Synchronous Hybrid Graduate Programmes: A Control-Value Approach. Res. Learn. Technol. 2015, 23. [CrossRef]

20. Cristina Stringher. Learning to Learn; Taylor \& Francis Group: Abingdon, UK, 2014. 
21. Hasan, N.; Bao, Y. Impact of "e-Learning Crack-up" Perception on Psychological Distress among College Students during COVID-19 Pandemic: A Mediating Role of "Fear of Academic Year Loss. " Child. Youth Serv. Rev. 2020, 118, 105355. [CrossRef]

22. John Brown and Richard Adler Minds on Fire: Open Education, the Long Tail, and Learning 2.0-Lou Pugliese. Available online: https:/ / www.loupugliese.com/publications/2019/1/17/minds-on-fire-open-education-the-long-tail-and-learning-20 (accessed on 2 May 2021).

23. Wang, T.-H.; Lin, H.-C.K.; Chen, H.-R.; Huang, Y.-M.; Yeh, W.-T.; Li, C.-T. Usability of an Affective Emotional Learning Tutoring System for Mobile Devices. Sustainability 2021, 13, 7890. [CrossRef]

24. Shim, T.E.; Lee, S.Y. College Students' Experience of Emergency Remote Teaching Due to COVID-19. Child. Youth Serv. Rev. 2020, 119, 105578. [CrossRef]

25. Sadeghi, M. Department of English, Tonekabon Branch, Islamic Azad University, Tonekabon, Iran A Shift from Classroom to Distance Learning: Advantages and Limitations. Int. J. Res. Engl. Educ. 2019, 4, 80-88. [CrossRef]

26. Murphy, M.P.A. COVID-19 and Emergency ELearning: Consequences of the Securitization of Higher Education for Post-Pandemic Pedagogy. Contemp. Secur. Policy 2020, 41, 492-505. [CrossRef]

27. Gherhes, V.; Stoian, C.E.; Fărcașiu, M.A.; Stanici, M. E-Learning vs. Face-To-Face Learning: Analyzing Students' Preferences and Behaviors. Sustainability 2021, 13, 4381. [CrossRef]

28. Hays, J.; Reinders, H. Sustainable Learning and Education: A Curriculum for the Future. Int. Rev. Educ. 2020, 66, 29-52. [CrossRef]

29. Le Grange, L.L.L. Sustainability and Higher Education: From Arborescent to Rhizomatic Thinking. Educ. Philos. Theory 2011, 43, 742-754. [CrossRef]

30. Burbules, N.C.; Fan, G.; Repp, P. Five Trends of Education and Technology in a Sustainable Future. Geogr. Sustain. 2020, 1, 93-97. [CrossRef]

31. Barth, M.; Michelsen, G.; Rieckmann, M.; Thomas, I. (Eds.) Routledge Handbook of Higher Education for Sustainable Development, 1st ed.; Routledge: London, UK, 2015; ISBN 978-1-317-91811-0.

32. Howlett, C.; Ferreira, J.-A.; Blomfield, J. Teaching Sustainable Development in Higher Education: Building Critical, Reflective Thinkers through an Interdisciplinary Approach. Int. J. Sustain. High. Educ. 2016, 17, 305-321. [CrossRef]

33. Azeiteiro, U.M.; Bacelar-Nicolau, P.; Caetano, F.J.P.; Caeiro, S. Education for Sustainable Development through E-Learning in Higher Education: Experiences from Portugal. J. Clean. Prod. 2015, 106, 308-319. [CrossRef]

34. Murray, J. Student-Led Action for Sustainability in Higher Education: A Literature Review. Int. J. Sustain. High. Educ. 2018, 19, 1095-1110. [CrossRef]

35. Holmén, J.; Adawi, T.; Holmberg, J. Student-Led Sustainability Transformations: Employing Realist Evaluation to Open the Black Box of Learning in a Challenge Lab Curriculum. Int. J. Sustain. High. Educ. 2021, 22, 1-24. [CrossRef]

36. Bączek, M.; Zagańczyk-Bączek, M.; Szpringer, M.; Jaroszyński, A.; Wożakowska-Kapłon, B. Students' Perception of Online Learning during the COVID-19 Pandemic: A Survey Study of Polish Medical Students. Medicine 2021, 100, e24821. [CrossRef]

37. Stöhr, C.; Adawi, T. Flipped Classroom Research: From "Black Box" to "White Box" Evaluation. Educ. Sci. 2018, 8, 22. [CrossRef]

38. Rodríguez Aboytes, J.G.; Barth, M. Transformative Learning in the Field of Sustainability: A Systematic Literature Review (1999-2019). Int. J. Sustain. High. Educ. 2020, 21, 993-1013. [CrossRef]

39. Macintyre, T.; Lotz-Sisitka, H.; Wals, A.; Vogel, C.; Tassone, V. Towards Transformative Social Learning on the Path to 1.5 Degrees. Curr. Opin. Environ. Sustain. 2018, 31, 80-87. [CrossRef]

40. Lotz-Sisitka, H.; Wals, A.E.; Kronlid, D.; McGarry, D. Transformative, Transgressive Social Learning: Rethinking Higher Education Pedagogy in Times of Systemic Global Dysfunction. Curr. Opin. Environ. Sustain. 2015, 16, 73-80. [CrossRef]

41. Illeris, K. Transformative Learning and Identity. J. Transform. Educ. 2014, 12, 148-163. [CrossRef]

42. Holmberg, J. 4. Transformative learning and leadership for a sustainable future: Challenge Lab at Chalmers University of Technology. In Intergenerational Learning and Transformative Leadership for Sustainable Futures; Corcoran, P.B., Hollingshead, B.P., Lotz-Sisitka, H., Wals, A.E.J., Weakland, J.P., Eds.; Wageningen Academic Publishers: Wageningen, The Netherlands, 2014; pp. 91-102, ISBN 978-90-8686-252-8.

43. Blake, J.; Sterling, S.; Goodson, I. Transformative Learning for a Sustainable Future: An Exploration of Pedagogies for Change at an Alternative College. Sustainability 2013, 5, 5347-5372. [CrossRef]

44. Birgili, B.; Seggie, F.N.; Oğuz, E. The Trends and Outcomes of Flipped Learning Research between 2012 and 2018 : A Descriptive Content Analysis. J. Comput. Educ. 2021, 8, 365-394. [CrossRef]

45. Ayuyang, R.R. Interactive Learning (ILEARN) Tool: An ELearning Portal Designed Using MOODLE for Cagayan State University in the Philippines. In Proceedings of the 2019 5th International Conference on Computing and Artificial Intelligence-ICCAI'19, Bali, Indonesia, 19-22 April 2021; ACM Press: Bali, Indonesia, 2019; pp. 11-16.

46. Svanström, M.; Lozano-García, F.J.; Rowe, D. Learning Outcomes for Sustainable Development in Higher Education. Int. J. Sustain. High. Educ. 2008, 9, 339-351. [CrossRef]

47. Jamison, A.; Kolmos, A.; Holgaard, J.E. Hybrid Learning: An Integrative Approach to Engineering Education: An Integrative Approach to Engineering Education. J. Eng. Educ. 2014, 103, 253-273. [CrossRef]

48. Wals, A.E.J.; Jickling, B. "Sustainability" in Higher Education: From Doublethink and Newspeak to Critical Thinking and Meaningful Learning. Int. J. Sustain. High. Educ. 2002, 3, 221-232. [CrossRef] 